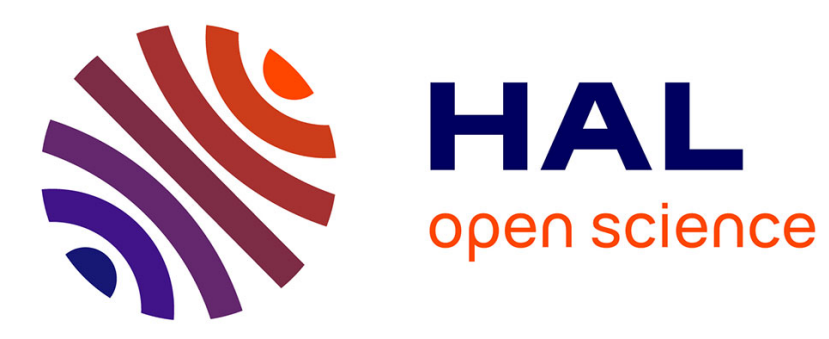

\title{
Energy and environmental analysis of an innovative system based on municipal solid waste (msw) pyrolysis and combined cycle
}

Paolo Baggio, Marco Baratieri, Andrea Gasparella, Giovanni A. Longo

\section{- To cite this version:}

Paolo Baggio, Marco Baratieri, Andrea Gasparella, Giovanni A. Longo. Energy and environmental analysis of an innovative system based on municipal solid waste (msw) pyrolysis and combined cycle. Applied Thermal Engineering, 2007, 28 (2-3), pp.136. 10.1016/j.applthermaleng.2007.03.028 . hal00498951

\section{HAL Id: hal-00498951 https://hal.science/hal-00498951}

Submitted on 9 Jul 2010

HAL is a multi-disciplinary open access archive for the deposit and dissemination of scientific research documents, whether they are published or not. The documents may come from teaching and research institutions in France or abroad, or from public or private research centers.
L'archive ouverte pluridisciplinaire HAL, est destinée au dépôt et à la diffusion de documents scientifiques de niveau recherche, publiés ou non, émanant des établissements d'enseignement et de recherche français ou étrangers, des laboratoires publics ou privés. 


\section{Accepted Manuscript}

Energy and environmental analysis of an innovative system based on municipal solid waste (msw) pyrolysis and combined cycle

Paolo Baggio, Marco Baratieri, Andrea Gasparella, Giovanni A. Longo

PII:

S1359-4311(07)00123-8

DOI:

10.1016/j.applthermaleng.2007.03.028

Reference:

ATE 2145

To appear in:

Applied Thermal Engineering

\section{APPLIED}

THERMAL

ENGINEERING

30 November 2006

Received Date:

2 March 2007

Revised Date:

25 March 2007

Accepted Date:

Please cite this article as: P. Baggio, M. Baratieri, A. Gasparella, G.A. Longo, Energy and environmental analysis of an innovative system based on municipal solid waste ( $\mathrm{msw}$ ) pyrolysis and combined cycle, Applied Thermal Engineering (2007), doi: 10.1016/j.applthermaleng.2007.03.028

This is a PDF file of an unedited manuscript that has been accepted for publication. As a service to our customers we are providing this early version of the manuscript. The manuscript will undergo copyediting, typesetting, and review of the resulting proof before it is published in its final form. Please note that during the production process errors may be discovered which could affect the content, and all legal disclaimers that apply to the journal pertain. 


\title{
ENERGY AND ENVIRONMENTAL ANALYSIS OF AN INNOVATIVE SYSTEM BASED ON MUNICIPAL SOLID WASTE (MSW) PYROLYSIS AND COMBINED CYCLE
}

\author{
Paolo Baggio $^{(1)}$, Marco Baratieri ${ }^{(1)}$, Andrea Gasparella ${ }^{(2)}$, Giovanni A. Longo ${ }^{(2) *}$ \\ ${ }^{(1)}$ University of Trento
}

Dept. of Civil and Environmental Engineering

Via Mesiano 77, 38050 Trento

ITALY

${ }^{(2)}$ University of Padova

Dept. of Management and Engineering

Str.lla S.Nicola 3, 36100 Vicenza

ITALY

* Corresponding Author:

Phone : +390444998726 Fax: +390444 $\quad$ F98888 E-mail: tony@ gest.unipd.it 


\section{ACCEPTED MANUSCRIPT}

\section{ABSTRACT}

This paper presents the energy and the environmental impact analysis of an innovative system based on the pyrolysis of MSW which produces solid (char), liquid (tar) and gas (syngas) fuels used in a combined cycle for electric power generation. The syngas, after filtration and compression, feeds two gas turbines. In turn, the exhaust from the gas turbines, after postcombustion with char and tar, drives a steam turbine power plant. Before being discharged, the flue gas is processed in an SCR (Selective Catalytic Reduction) unit to reduce CO, VOC and $\mathrm{NO}_{\mathrm{x}}$ content and is filtered to remove particulate matter.

This innovative approach to energy recovery from MSW combines high energy efficiency with a low level of polluting emissions. The estimated global efficiency of the plant, referred to the LHV of the MSW, is around 28-30\%, a much higher value than ordinarily obtained in traditional waste incineration plants. The environmental analysis includes a study of the polluting emissions and the simulation of their concentration in the area surrounding the plant: the emissions of the plant have a negligible influence on the original polluting levels of the settlement area.

\section{KEYWORDS}

Municipal Solid Waste, Pyrolysis, Heat Recovery, Combined Cycle, Environmental Impact 


\section{ACCEPTED MANUSCRIPT}

\section{INTRODUCTION}

The beginning of the third millennium has been characterised by a progressive increase in the demand for fossil fuels, which has caused a steep rise in oil price. At the same time, several environmental disasters have increased the sensitivity of world-wide public opinion towards the effect that environmental pollution has on human health and climate change. These conditions have fostered a renewed interest in renewable energy: solar energy, wind energy, biomass and solid wastes.

In addition, the disposal of Municipal Solid Waste (MSW) has become a critical and costly problem. The traditional landfill method requires large amounts of land and contaminates air, water and soil. As an alternative, the incineration method has the advantage of reducing waste volume, and it may also generate thermal and electric energy with low polluting emissions in the atmosphere [1]. Therefore, those countries where land resources are limited, such as in the EU and Japan, prefer burning trash, whereas countries with vast territories, such as the US and Canada, continue to apply landfill disposal.

The new MSW management strategies are based on selection, recycle and energy recovery. The development of innovative technologies for energy recovery from MSW could contribute to the reduction of both environmental pollution and dependence on fossil fuels. The alternative options to recover energy from MSW are incineration and pyrolysis / gasification. Incineration is a destructive process in which the hydrocarbon content of MSW is converted into flue gases at high temperature whereas pyrolysis / gasification may convert it into other hydrocarbons which may be utilized as fuels, new materials and also monomers $[2,3,4,5,6]$.

This paper analyses an innovative system exploiting the pyrolysis of MSW to produce solid, liquid and gaseous fuels used in a combined cycle for electric power generation. This system will be analysed to evaluate its global energy efficiency and its environmental impact on the surrounding area. 


\section{SYSTEM DESCRIPTION}

The system, shown in figure 1, consists of two pyrolysis lines, which feed two gas turbines. The exhaust from the gas turbine outlets, after post-combustion in a steam boiler, drives a steam turbine. The MSW, processed in a rotary kiln at $500-600^{\circ} \mathrm{C}$ in absence of air, produces solid (char), liquid (tar) and gaseous (syngas) fuels together with ash. Pyrolysis is an endothermic process which requires a thermal energy input obtained from the combustion of a fraction of char and tar. The syngas available at the outlet of the rotary kiln is purified in a cyclone and a scrubber to remove particulate matter and condense humidity and heavy hydrocarbon vapours. The syngas is then compressed and injected into the combustion chamber of the gas turbines.

The combustion of the syngas in the gas turbines occurs with high excess air (300-400\%). Therefore the gas exhaust from the gas turbines may be used as reactant in the recovery boiler for the combustion of char and tar in order to drive the steam turbine. Before being discharged, the flue gas is processed in an SCR (Selective Catalytic Reduction) unit integrated in the boiler to reduce $\mathrm{CO}, \mathrm{VOC}$ and $\mathrm{NO}_{\mathrm{x}}$ content and is filtered to remove particulate matter. The SCR technology combines the catalytic reduction of carbon monoxide and volatile organic compounds by noble metals with the reduction of nitrogen oxides into molecular nitrogen and water vapour by using ammonia or urea as reactants in the presence of titanium and vanadium catalysts.

The system proposed shows some innovative aspects with respect to traditional MSW plants:

1) The energy recovery on MSW is carried out by using a combined cycle instead of a simple steam turbine as in the traditional MSW incineration plants or a gas turbine or a reciprocating engine as in the MSW gasification plants. The application of a combined 


\section{ACCEPTED MANUSCRIPT}

cycle allows a rational use of the different products resulting from the MSW pyrolysis (syngas, char, tar) increasing the conversion efficiency.

2) The system proposed shows specific plant engineering advantages:

- high flexibility: it is possible to modulate the power simply by turning-off one of the two pyrolysis lines.

- high reliability: when the pyrolysis lines are out of order it is possible to send the MSW directly to the steam boiler and the plant works as a traditional incineration one.

- low polluting emissions: the presence of a single line of flue gas simplifies the treatment to reduce polluting emissions

\section{ENERGY ANALYSIS}

The composition of the MSW depends upon variables such as geographical area, population density, climatic conditions and waste management policies. MSW eligible for heat recovery typically contains $60 \mathrm{wt} \%$ cellulosic fraction (paper, cardboard, wood), $20 \mathrm{wt} \%$ plastics (highdensity polyethylene (HDPE), low density polyethylene (LDPE), polypropylene (PP), polystyrene (PS), polyvinilchloride (PVC)) and $20 \mathrm{wt} \%$ moisture. Table 1 shows the MSW composition and heating value assumed in the present analysis: these values are typical for developed countries, as shown in [7]. The MSW has a Higher Heating Value (HHV) around 19.2 $\mathrm{MJ} / \mathrm{kg}$, an equivalent molecular mass $\mathrm{MMSW}=25.49 \mathrm{~kg} / \mathrm{kmol}$ and the following equivalent raw chemical formula:

$$
\mathrm{C} \mathrm{H}_{1.515} \mathrm{O}_{0.43}+0.283 \mathrm{H}_{2} \mathrm{O}+\mathrm{ASH}
$$




\section{ACCEPTED MANUSCRIPT}

The thermochemical conversion of MSW into gaseous fuel may be obtained by gasification or pyrolysis.

Gasification is a high temperature $\left(700-800^{\circ} \mathrm{C}\right)$ thermal process, requiring the addition of air and/or steam, which produces a high fraction of syngas and small quantities of char, tar and ash. However the syngas obtained can have a poor heating value due to the high content of $\mathrm{N}_{2}$, and $\mathrm{CO}_{2}$.

Pyrolysis is a thermal process evolving in absence of air at temperatures around $500-600^{\circ} \mathrm{C}$ which produces syngas, char and tar in fractions depending upon operating temperature, heating rate and residence time. For high tar yield, a high heating rate and short residence time are requested (Fast Pyrolysis). To maximise char and syngas yields, a low heating rate and, a long residence time should be applied (Slow Pyrolysis).

The char fraction contains carbonaceous residues derived from thermal decomposition of the organic components, unconverted organic solid and ash resulting from inorganic materials. Its heating value is comparable with those of lignite and coke.

The tar fraction is a complex liquid mixture containing resins, acids, alcohols, intermediate carbohydrates, phenols, aromatics, and aldehydes. Its heating value is comparable with those of oxygenated fuels $\left(\mathrm{CH}_{3} \mathrm{OH}, \mathrm{C}_{2} \mathrm{H}_{5} \mathrm{OH}\right)$.

The composition of the syngas depends on the MSW characteristics, moisture content, operating temperature and residence time. The heating value of syngas is comparable with that of coal gas and is much lower than that of natural gas.

The accurate prediction of the syngas composition requires a complex kinetic model capable of accounting for all pyrolysis reactions taking place inside the rotary kiln. The present paper is based on a simpler equilibrium model. Clearly this approach gives only a rough estimation of the syngas composition, as normally it is not possible to achieve complete thermodynamic equilibrium inside a pyrolysis reactor. Nevertheless the predictions of equilibrium models are 


\section{ACCEPTED MANUSCRIPT}

not far-away from the experimental results both for gasification of biomass $[8,9,10,11]$ and gasification of coal $[12,13]$.

The thermodynamic equilibrium model used in present paper is a two-phase (gas+solid) one, allowing to predict not only the syngas composition but also the tar+char fraction. Despite the apparent crudeness of the approach, it's nevertheless a valuable engineering aid, usually leading to errors smaller than $20 \%$ with respect to the actual results [14]. To the authors knowledge, this approach has never before been applied to a similar plant operation analysis.

The global chemical reaction relative to MSW pyrolysis is:

$$
\mathrm{CH}_{\alpha} \mathrm{O}_{\beta}+\mathrm{yO}_{2}+\mathrm{zN}_{2}+\mathrm{wH}_{2} \mathrm{O}=\mathrm{x}_{1} \mathrm{C}+\mathrm{x}_{2} \mathrm{H}_{2}+\mathrm{x}_{3} \mathrm{H}_{2} \mathrm{O}+\mathrm{x}_{4} \mathrm{CO}+\mathrm{x}_{5} \mathrm{CO}_{2}+\mathrm{x}_{6} \mathrm{CH}_{4}+\mathrm{x}_{7} \mathrm{O}_{2}+\mathrm{x}_{8} \mathrm{~N}_{2}(2)
$$

where $\mathrm{CH}_{\alpha} \mathrm{O}_{\beta}$ is the MSW equivalent chemical formula, $\mathrm{y}, \mathrm{z}$ and $\mathrm{w}$ the moles of other reactants and $\mathrm{x}_{\mathrm{i}}$ the moles of reaction products. Assuming negligible presence of air, the composition of the reagents is:

$$
\alpha=1.515 \quad \beta=0.430 \quad \mathrm{y}=0.000 \quad \mathrm{z}=0.000 \quad \mathrm{w}=0.283
$$

The equilibrium composition can be estimated minimising the total free energy of the system and verifying the conservation of mass and chemical species. The resulting set of non-linear equations is solved by iteration obtaining the moles $x_{i}$ of reaction products and therefore the composition of syngas.

A specific computer code has been developed in Matlab using the software Cantera [15] for the computation of thermochemical properties.

From the composition of the pyrolysis products it is possible to evaluate the heating value and the thermal energy input requested by the pyrolysis, i.e.: 


$$
\mathrm{Q}_{\mathrm{PIR}}=\left[\left(\Sigma_{\mathrm{i}} \mathrm{x}_{\mathrm{i}} \mathrm{h}_{\mathrm{i}}\right)_{\text {PRODUCTS }}-\left(\Sigma_{\mathrm{j}} \mathrm{y}_{\mathrm{j}} \mathrm{h}_{\mathrm{j}}\right)_{\text {REAGENTS }}\right] / \mathrm{M}_{\mathrm{MSW}}
$$

where $\mathrm{Xi}$ and $\mathrm{h}_{\mathrm{i}}$ are the moles and the specific molar enthalpy of the reaction products, $\mathrm{y}_{\mathrm{j}}$ and $h_{j}$ the moles and the specific molar enthalpy of the reagents.

Table 2 gives the characteristics of the pyrolysis products at the outlet of the scrubber for a pyrolysis temperature at $500^{\circ} \mathrm{C}$. The pyrolysis at $500^{\circ} \mathrm{C}$ of $1 \mathrm{~kg}$ of $\mathrm{MSW}$ generates around $300 \mathrm{~g}$ of syngas together with $700 \mathrm{~g}$ of char $+\operatorname{tar}$ and requires $1.8 \mathrm{MJ}$ of thermal energy input equal to $9.2 \%$ of the MSW High Heating Value (HHV).

The processes inside the syngas compressor, gas turbines, recovery boiler and steam turbine have been simulated by assuming suitable operating conditions, efficiency and effectiveness. Table 3 gives the main assumptions and table 4 shows the mass flow rates $G$, the heat flow rates $\mathrm{q}$, the electric power $\mathrm{W}$ and the efficiency $\eta$ computed for a pyrolysis temperature of $500^{\circ} \mathrm{C}$.

The global efficiency of the system is equal to the ratio between the net electric power produced and the input thermal power of the MSW referred to its Lower Heating Value (LHV):

$$
\eta_{\mathrm{GLOBAL}}=\left(\mathrm{W}_{\mathrm{GAS} T \mathrm{TUB}}+\mathrm{W}_{\mathrm{STEAM}} \mathrm{TURB}\right) /\left(\mathrm{G}_{\mathrm{MSW}} \mathrm{LHV}_{\mathrm{MSW}}\right)
$$

The system is fed with 34.8 MWt of MSW and produces 9.84 MWel of electric power with a global efficiency of $28.3 \%$. The steam turbine provides $7.47 \mathrm{MWel}(76 \%)$ with an efficiency around $29.5 \%$, whereas the gas turbines provide $2.36 \mathrm{MW}(24 \%)$ with an efficiency around $18.6 \%$. The poor performance of the gas turbines is due both to operating conditions (maximum temperature around $1000^{\circ} \mathrm{C}$ and pressure ratio around 12) and the energy 


\section{ACCEPTED MANUSCRIPT}

consumption for syngas compression (amounting to $17.3 \%$ of the electric power produced by the gas turbines).

A sensitivity analysis has been carried out to evaluate the effect of a temperature increase of pyrolysis from 500 to $600^{\circ} \mathrm{C}$. Figure 2 shows the electric power output against the pyrolysis temperature ranging from 500 to $600^{\circ} \mathrm{C}$. The syngas yield rises from 30 to $40 \%$ increasing the contribution of the gas turbines and reducing the output of the steam cycle. As a consequence, the total electric power of the system shows only a slight increase from 9.84 to $10 \mathrm{MWel}$.

\section{ENVIRONMENTAL ANALYSIS}

The polluting emissions of the plant for MSW treatment must be added to the original polluting levels of the proposed settlement area, Porto Marghera, a high density industrial area near Venice (Italy). A comparative analysis is carried out comparing the emissions of the MSW treatment plant to those of the nearest power plant, the ENEL thermo-electric power plant "Andrea Palladio" which is $1200 \mathrm{~m}$ distant. This power plant is instrumented with a complete set of emissions control devices: SCR unit, FGD (Flue Gas Desulphuration) unit, bag filters. The MSW plant will probably use emission control devices of a better quality level. Moreover the pyrolysis reactor will be fed with selected MSW which estimated composition is reported in table 1: only PVC plastic shows a significant chlorine content. However the percentage of PVC plastic in the MSW allows to conclude that the emission of gases containing chlorine from the MSW plant should be limited.

The concentration of polluting substances in air derives from the combined effects of the polluting emissions, storage and dispersion in the atmosphere. The storage and dispersion

processes, which depend mainly on meteorological conditions, cannot be influenced; therefore the only possible positive action consists in reducing the emissions. 


\section{ACCEPTED MANUSCRIPT}

The analysis of polluting storage and dispersion in the atmosphere requires meteorological information (windiness, solar radiation, atmospheric stability, etc.) which can be derived from the statistical analysis of local meteorological data.

The numerical simulation of polluting emissions, dispersion and fallout was carried out by using the ISC dispersion model implemented by US EPA [16]. The ISC is a threedimensional, steady state, gaussian model that computes the average annual concentration and the fallout of polluting substances emitted by concentrated or distributed sources. The model is based on the solution of the convective-diffusion equation modified to account for meteorological and orographical conditions.

The polluting emissions considered in the present analysis are $\mathrm{SO}_{\mathrm{x}}, \mathrm{NO}_{\mathrm{x}}$, particulate matter and CO. It must be noted that, because of the characteristics of the waste fed to the plant, i.e. mainly cardboard and plastics from packing material, a negligible sulphur (S) content is expected, and then the assumed value of $\mathrm{SO}_{2}$ concentration in the flue gas must be considered to be a worst case scenario.

The plant processes about $7200 \mathrm{~kg} / \mathrm{h}$ of CDR and discharges about $56600 \mathrm{Nm}^{3} / \mathrm{h}$ of exhaust into the atmosphere. The concentration of the polluting substances in the exhaust was derived from the measured values on the waste incineration plant of Bolzano (Italy) which is equipped with pollution control systems (including an SCR unit and bag filters) similar to the ones of the MSW plant considered [17].

The polluting emissions of the ENEL thermo-electric power plant "Andrea Palladio" were derived from the 2004 report on plant operation [18].

The exhaust discharge temperature is $200^{\circ} \mathrm{C}$ for the $\mathrm{MSW}$ plant and $130^{\circ} \mathrm{C}$ for the power plant, whereas the chimney height is around $50 \mathrm{~m}$ for the MSW plant and ranges between 65 and $130 \mathrm{~m}$ for the power plant. The meteorological data used for the simulation was derived from [19]. The computational domain for the numerical simulation is a squared area $10 \mathrm{~km}$ 


\section{ACCEPTED MANUSCRIPT}

each side. Tables 5 and 6 show the polluting substances concentration in the exhaust and the annual polluting emissions of the MSW plant and the power plant, respectively.

Figures 3 and 4 show the $\mathrm{SO}_{2}$ concentration in the air at ground level caused by the emissions of the power plant and the MSW plant, respectively.

Figures 5 and 6 show the $\mathrm{NO}_{\mathrm{x}}$ concentration in the air at ground level caused by the emissions of the power plant and the MSW plant, respectively.

Figures 7 and 8 show the particulate concentration in the air at the ground level caused by the power plant and the MSW plant, respectively.

Figures 9 and 10 show the $\mathrm{CO}$ concentration in the air at ground level caused by the emissions of the power plant and the MSW plant, respectively.

Table 7 shows the maximum concentration of the polluting substances in the air at ground level caused by the MSW plant alone, the power plant alone and the combined effect of both plants. The polluting emissions of the MSW plant are negligible respect to those of the power plant, except for $\mathrm{CO}$ emission. This result is obvious, considering the difference in size between the two plants: the electrical power of the MWS plant (10 MWe) is approximately 100 times lower than that of the power plant $(1 \mathrm{GWe})$. Therefore, it is useful to compare the specific polluting emissions of the plants equal to the ratio between the annual polluting emissions and the annual electric energy production: table 8 shows this comparison. The specific polluting emissions of the MSW plant are generally lower than those of the power plant. The $\mathrm{SO}_{2}$ specific emission is exactly 6.6 times lower (worst case scenario), the $\mathrm{NO}_{\mathrm{x}}$ is 2.9 times lower, whereas the particulate specific emission is almost equal and the CO specific emission is 2.6 times higher. The polluting emissions of the MSW plant are even more negligible when compared to the total polluting emissions of all power plants in Porto Marghera (2 GWe)

Table 9 shows the comparison between the annual polluting emissions of the MSW plant and 


\section{ACCEPTED MANUSCRIPT}

those of all power plants in Porto Marghera. The data on the polluting emissions of all power plants in Porto Marghera is derived from [20].

\section{CONCLUSION}

This paper presents the feasibility study of an innovative plant based on MSW pyrolysis and combined cycle.

The coupling between pyrolysis and combined cycle ensures a conversion efficiency of MSW into electric energy of about $28-30 \%$, a significantly higher value respect to traditional waste incineration plants.

The pyrolysis temperature only affects the distribution of the electric power production between gas and steam turbines, whereas it shows only a slight effect on the performance of the whole system.

The polluting emissions of the innovative MSW plant are negligible in term of absolute contribution and are generally lower in term of specific contribution with respect to those of the ENEL thermo-electric power plant "Andrea Palladio", except for CO emission. The polluting emissions of the MSW plant are even more negligible when compared to the polluting emissions of all power plants in Porto Marghera.

This feasibility study has been carried out with well established mathematical models which ability is recognised in literature. The integral experimental validation of the simulation required the realisation of a demonstrative plant which is out of the purpose of a feasibility study and, by the way, the possibility to build a pilot and/or full scale plant is currently under evaluation. If and when such plant will be operational, the authors will be glad to present the experimental results. 
The feasibility study requires also an economic assessment of the innovative plant. However this study, due to the complexity of the plant and the different levels of electricity prices and MSW disposal tariffs, needs a specific paper to be carried out. In present paper it is possible to give only a first rough estimation of the pay-back time of the plant: around 8-10 years.

\section{ACKNOWLEDGEMENTS}

This research project was funded by Regione Veneto (Italy) DOCUP Obiettivo n. 2 - 20002006 - Misura 2.3: “Attività di ricerca e trasferimento di tecnologia”. 


\section{ACCEPTED MANUSCRIPT}

\section{NOMENCLATURE}

G

HHV

$\mathrm{h}_{\mathrm{i}}$

LHV

M

MSW

$\mathrm{P}$

Q

Q

$\mathrm{R}_{\mathrm{p}}$

$\mathrm{T}$

W

$\mathrm{X}_{\mathrm{i}}$

$\mathrm{Yi}_{\mathrm{i}}$

$\varepsilon$

$\eta$
Mass flow rate

Higher Heating Value

Specific molar enthalpy

Lower Heating Value

Molecular mass

Municipal Solid Waste

Pressure

Heat flow rate

Specific heat

Pressure ratio

Temperature

Electrical power

Moles of reagents

Moles of products

Effectiveness

Efficiency $\mathrm{kg} / \mathrm{s}$

$\mathrm{MJ} / \mathrm{kg}$

$\mathrm{kJ} / \mathrm{kmol}$

$\mathrm{MJ} / \mathrm{kg}$

$\mathrm{kg} / \mathrm{kmol}$

$\mathrm{Pa}$

W

$\mathrm{W} / \mathrm{kg}$

K

W

kmol

kmol 


\section{ACCEPTED MANUSCRIPT}

\section{REFERENCES}

[1] Porteous, A., Energy from waste incineration - a state of the art emissions review with enphasis on public acceptability, Applied Energy, 70 (2001) 157-167

[2] Bridgwater, A.V., Meier, D., Radlein, D., An overview of fast pyrolysis of biomass, Organic Geochemistry, 30 (1999) 1479-1493

[3] Kiran, N., Ekinci, E., Snape, C.E., Recycling of plastic wastes via pyrolysis, Resources, Conservation \& Recycling, 29 (2000) 273-283

[4] Yaman, S., Pyrolysis of biomass to produce fuels and chemical feedstocks, Energy Conversion \& Management, 45 (2004), 651-671

[5] Demirbas, A., Pyrolysis of municipal plastic wastes for recovery of gasoline-range hydrocarbons, J. Analytical and Applied Pyrolysis 72 (2004) 97-102

[6] Bebar, L., Stehlik, P., Havlen, L., Oral, J., Analysis of using gasification and incineration for thermal processing of wastes, Applied Thermal Eng. 25 (2005) 1045-1055

[7] Sørum, L., Grønli, M.G., Hustad, J.E., Pyrolysis characteristics and kinetics of municipal solid wastes, Fuel, 80 (2001) 1217-1227

[8] Kinoshita, C.M., Wang, Y., Takahashi, P.K., Chemical equilibrium computations for gasification of biomass to produce methanol, Energy Sources, 13 (1991) 361-368

[9] Wang, Y., Kinoshita, C.M., Experimental analysis of biomass gasification with steam and oxygen, Solar Energy, 49 (1992) 153-158.

[10] Schuster, G., Löffler, G., Weigl, K., Hofbauer, H., Biomass steam gasification - an extensive parametric modeling study, Bioresource Technology, 77 (2001) 71-79.

[11] Altafini, C.R., Wander P.R., Barreto, R.M., Prediction of the working parameters of a wood waste gasifier through an equilibrium model, Energy Conversion \& Manag., 44 (2003) 2763-2777. 


\section{ACCEPTED MANUSCRIPT}

[12] Altafini, C.R., Mirandola, A., A chemical equilibrium model of the coal gasification process based on the minimization of the Gibbs free energy, Proc. of Flowers'97, 1997, Florence, Italy, 419-427.

[13] Li, X., Grace, J.R., Watkinson, A.P., Lim, C.J., Ergüdenler, A., Equilibrium modelling of gasification: a free energy minimization approach and its application to a circulating fluidized bed coal gasifier, Fuel, 80 (2001) 195-207.

[14] Baratieri, M., Biomass thermochemical conversion: process analysis and energy performances, University of Trento, Italy, 2007, PhD Thesis.

[15] Goodwin, D.G., Cantera: object-oriented software for reacting flows, California Institute of Technology (Caltech), 2005, www.cantera.org.

[16] U.S. EPA, User's guide for the Industrial Source Complex (ISC3) dispersion models, Reports EPA-454/B-95-003a and 003b, September 1995.

[17] Termovalorizzatore di Bolzano (www.eco-center.it)

[18] ENEL s.p.a., Dichiarazione ambientale anno 2004, Impianto termoelettrico "Andrea Palladio" Fusina (Venezia), 2005.

[19] Ente Zona Industriale di Porto Marghera (www.entezona.it)

[20] ARPAV, Regione Veneto, Rapporto Ambientale d'Area di Porto Marghera - Bilancio Ambientale 1998 - 2004, 2005. 


\section{CAPTION TO THE FIGURES}

Figure 1. Schematic diagram of an innovative system for Municipal Solid Waste (MSW) pyrolysis.

Figure 2. Electric power output vs. pyrolysis temperature.

Figure 3. $\mathrm{SO}_{2}$ concentration in the air at ground level caused by the emissions of the power plant.

Figure 4. $\mathrm{SO}_{2}$ concentration in the air at ground level caused by the emissions of the MSW plant.

Figure 5. $\mathrm{NO}_{\mathrm{x}}$ concentration in the air at ground level caused by the emissions of the power plant.

Figure 6. $\mathrm{NO}_{\mathrm{x}}$ concentration in the air at ground level caused by the emissions of the MSW plant.

Figure 7. Particulate concentration in the air at ground level caused by the emissions of the power plant.

Figure 8. Particulate concentration in the air at ground level caused by the emissions of the MSW plant.

Figure 9. CO concentration in the air at ground level caused by the emissions of the power plant.

Figure 10. CO concentration in the air at ground level caused by the emissions of the MSW plant. 


\section{ACCEPTED MANUSCRIPT}

Table 1. Composition and heating value of MSW.

\begin{tabular}{lcccccccccc}
\hline & Paper Cardboard & Wood HDPE LDPE & PP & PS & PVC & H$_{2}$ O & MSW \\
\hline wt\% & 32.0 & 24.0 & 4.0 & 4.0 & 4.0 & 4.0 & 4.0 & 4.0 & 20.0 & $=$ \\
\hline $\mathbf{C}(\mathbf{w t} \%)$ & 52.1 & 48.6 & 47.4 & 86.1 & 85.7 & 86.1 & 92.1 & 41.4 & $=$ & 45.9 \\
\hline $\mathbf{H}(\mathbf{w t} \%)$ & 5.9 & 6.2 & 6.3 & 13.0 & 14.2 & 13.7 & 7.9 & 5.3 & $=$ & 5.8 \\
\hline $\mathbf{O}(\mathbf{w t} \%)$ & 41.9 & 45.0 & 46.2 & 0.9 & 0.1 & 0.2 & 0.0 & 5.8 & $=$ & 26.3 \\
\hline $\mathbf{H} \mathbf{O}(\mathbf{w t})$ & $=$ & $=$ & $=$ & $=$ & $=$ & $=$ & $=$ & $=$ & 20.0 & 20.0 \\
\hline $\mathbf{A S H}(\mathbf{w t} \%)$ & 1.0 & 8.4 & 0.2 & 0.0 & 0.0 & 0.0 & 0.0 & 0.4 & $=$ & 2.0 \\
\hline HHV(MJ/kg) & 19.3 & 16.9 & 19.3 & 46.4 & 46.6 & 46.4 & 42.1 & 22.8 & $=$ & 19.2 \\
\hline
\end{tabular}




\section{ACCEPTED MANUSCRIPT}

Table 2. Characteristics of pyrolysis products.

\begin{tabular}{|c|c|}
\hline Parameters & Values \\
\hline $\mathrm{T}_{\mathrm{PYR}}$ & $500^{\circ} \mathrm{C}$ \\
\hline pPYR & $101325 \mathrm{~Pa}$ \\
\hline $\mathrm{M}_{\mathrm{MSW}}$ & $25.49 \mathrm{~kg} / \mathrm{kmol}$ \\
\hline $\mathrm{HHV}_{\mathrm{MSW}}$ & $19.2 \mathrm{MJ} / \mathrm{kg}$ \\
\hline $\mathrm{H}_{2}$ & $3.16 \mathrm{wt} \%_{\mathrm{MSW}} \quad 10.9 \%_{\mathrm{SYNGAS}}$ \\
\hline $\mathrm{CH}_{4}$ & $4.84 \mathrm{wt} \%_{\mathrm{MSW}} \quad 16.6 \%_{\mathrm{SYNGAS}}$ \\
\hline $\mathrm{CO}$ & $2.05 \mathrm{wt} \%_{\mathrm{MSW}} \quad 7.0 \%_{\mathrm{SYNGAS}}$ \\
\hline $\mathrm{CO}_{2}$ & $19.09 \mathrm{wt} \%_{\mathrm{MSW}} \quad 65.5 \% \%_{\mathrm{SYNGAS}}$ \\
\hline $\mathrm{C}$ & $36.18 \mathrm{wt} \%_{\mathrm{MSW}} \quad 51.1 \%_{\mathrm{CHAR}+\mathrm{TAR}}$ \\
\hline $\mathrm{H}_{2} \mathrm{O}$ & $32.67 \mathrm{wt} \%_{\mathrm{MSW}} \quad 46.1 \%_{\mathrm{CHAR}+\mathrm{TAR}}$ \\
\hline ASH & $2.00 \mathrm{wt} \%_{\mathrm{MSW}} \quad 2.8 \%_{\mathrm{CHAR}+\mathrm{TAR}}$ \\
\hline GAS & $0.2915 \mathrm{~kg} / \mathrm{kg}_{\mathrm{MSW}}$ \\
\hline $\mathrm{HHV}_{\text {SYNGAS }}$ & $25.3 \mathrm{MJ} / \mathrm{kg}$ \\
\hline LHV $_{\text {SYNGAS }}$ & $22.0 \mathrm{MJ} / \mathrm{kg}$ \\
\hline CHAR+TAR & $0.7085 \mathrm{~kg} / \mathrm{kg}_{\mathrm{MSW}}$ \\
\hline $\mathrm{HHV}_{\mathrm{CHAR+TAR}}$ & $16.7 \mathrm{MJ} / \mathrm{kg}$ \\
\hline $\mathrm{LHV}_{\mathrm{CHAR}+\mathrm{TAR}}$ & $15.6 \mathrm{MJ} / \mathrm{kg}$ \\
\hline QPYR & $1.772 \mathrm{MJ} / \mathrm{kg}_{\mathrm{MSW}}$ \\
\hline
\end{tabular}


Table3.Operating conditions and efficiencies.

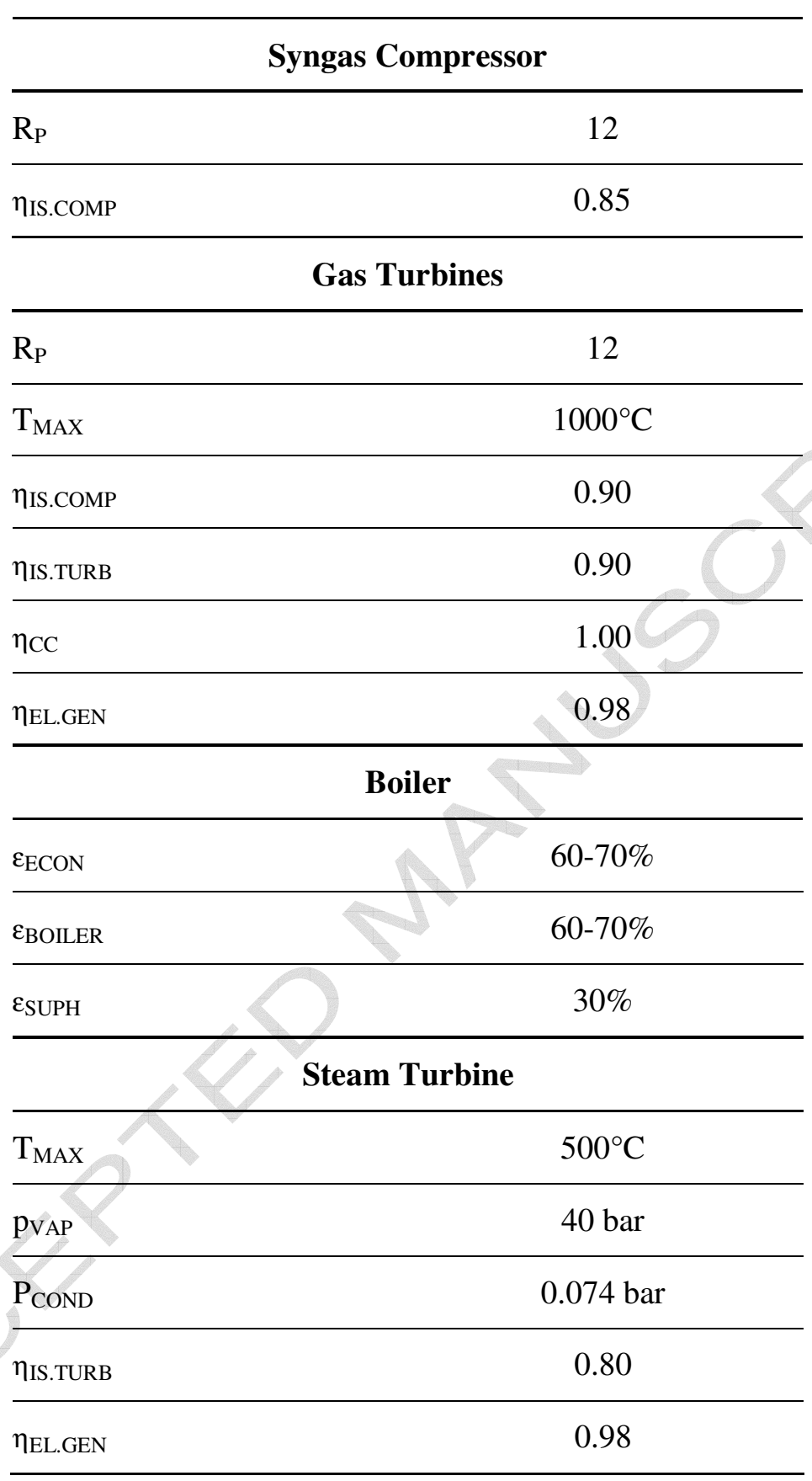


Table 4. Power and efficiency.

\begin{tabular}{ll}
\hline Parameters & Values \\
\hline $\mathrm{G}_{\mathrm{MSW}}$ & $7200 \mathrm{~kg} / \mathrm{h}$ \\
\hline $\mathrm{G}_{\text {SYnAS }}$ & $2100 \mathrm{~kg} / \mathrm{h}$ \\
\hline $\mathrm{G}_{\mathrm{CHAR}+\mathrm{TAR}}$ & $5100 \mathrm{~kg} / \mathrm{h}$ \\
\hline $\mathrm{W}_{\mathrm{GAS} \text { TURB }}$ & $2368 \mathrm{~kW}$ \\
\hline $\mathrm{W}_{\text {STEAM TURB }}$ & $7468 \mathrm{~kW}$ \\
\hline $\mathrm{W}_{\mathrm{GLOBAL}}$ & $9836 \mathrm{~kW}$ \\
\hline $\mathrm{q}_{\text {PYR }}$ & $3544 \mathrm{~kW}$ \\
\hline $\mathrm{q}_{\text {BOILER }}$ & $25314 \mathrm{~kW}$ \\
\hline $\mathrm{Q}_{\mathrm{MSW}}$ & $34781 \mathrm{~kW}$ \\
\hline$\eta_{\text {GAS TURB }}$ & $18.6 \%$ \\
\hline$\eta_{\mathrm{STEAM} \mathrm{TURB}}$ & $29.5 \%$ \\
\hline$\eta_{\text {GLOBAL }}$ & $28.3 \%$ \\
\hline
\end{tabular}


Table 5. Polluting substance concentration in the exhaust at the chimney (dry basis, normalized to $11 \% \mathrm{O}_{2}$ content for the MSW Plant and to $6 \% \mathrm{O}_{2}$ content for the Power Plant).

\begin{tabular}{lcc}
\hline & MSW Plant & Power Plant \\
\hline $\mathrm{SO}_{2}\left[\mathrm{mg} / \mathrm{Nm}^{3}\right]$ & 36.1 & 546.5 \\
\hline $\mathrm{NO}_{\mathrm{x}}\left[\mathrm{mg} / \mathrm{Nm}^{3}\right]$ & 44.5 & 293.9 \\
\hline Partic. $\left[\mathrm{mg} / \mathrm{Nm}^{3}\right]$ & 3.6 & 8.8 \\
\hline $\mathrm{CO}\left[\mathrm{mg} / \mathrm{Nm}^{3}\right]$ & 18.0 & 16.5 \\
\hline
\end{tabular}


Table 6. Annual polluting emissions.

\begin{tabular}{lcc}
\hline & MSW Plant & Power Plant \\
\hline $\mathrm{SO}_{2}$ [t/year] & 24.8 & 12562 \\
\hline $\mathrm{NO}_{\mathrm{x}}$ [t/year] & 30.6 & 6685 \\
\hline Partic. [t/year] & 2.5 & 193 \\
\hline CO [t/year] & 12.4 & 367 \\
\hline
\end{tabular}




\section{ACCEPTED MANUSCRIPT}

Table 7. Maximum polluting substance concentration in the air at ground level.

\begin{tabular}{lccc}
\hline & MSW plant & Power plant & MSW + Power plant \\
\hline $\mathrm{SO}_{2}\left[\mu \mathrm{g} / \mathrm{m}^{3}\right]$ & 0.350 & 24.00 & 24.00 \\
\hline $\mathrm{NO}_{\mathrm{x}}\left[\mu \mathrm{g} / \mathrm{m}^{3}\right]$ & 0.440 & 11.00 & 11.00 \\
\hline Partic. $\left[\mu \mathrm{g} / \mathrm{m}^{3}\right]$ & 0.035 & 0.28 & 0.28 \\
\hline $\mathrm{CO}\left[\mu \mathrm{g} / \mathrm{m}^{3}\right]$ & 0.180 & 0.32 & 0.38 \\
\hline
\end{tabular}


Table 8. Specific polluting emissions.

\begin{tabular}{ccc}
\hline & MSW Plant & Power Plant \\
\hline $\mathrm{SO}_{2}[\mathrm{mg} / \mathrm{kWh}]$ & 287.9 & 1909.4 \\
\hline $\mathrm{NO}_{\mathrm{x}}[\mathrm{mg} / \mathrm{kWh}]$ & 355.1 & 1016.1 \\
\hline Partic. $[\mathrm{mg} / \mathrm{kWh}]$ & 28.8 & 29.3 \\
\hline $\mathrm{CO}[\mathrm{mg} / \mathrm{kWh}]$ & 143.9 & 55.8 \\
\hline
\end{tabular}


Table 9. Annual polluting emissions.

\begin{tabular}{lcc}
\hline & MSW Plant & All Power Plants \\
\hline $\mathrm{SO}_{2}[\mathrm{t} /$ year] & 24.8 & 19858 \\
\hline $\mathrm{NO}_{\mathrm{x}}[\mathrm{t} /$ year$]$ & 30.6 & 12996 \\
\hline Partic. [t/year] & 2.5 & 355 \\
\hline $\mathrm{CO}[\mathrm{t} /$ year] & 12.4 & 573 \\
\hline
\end{tabular}




\section{ACCEPTED MANUSCRIPT}

Fig. 1

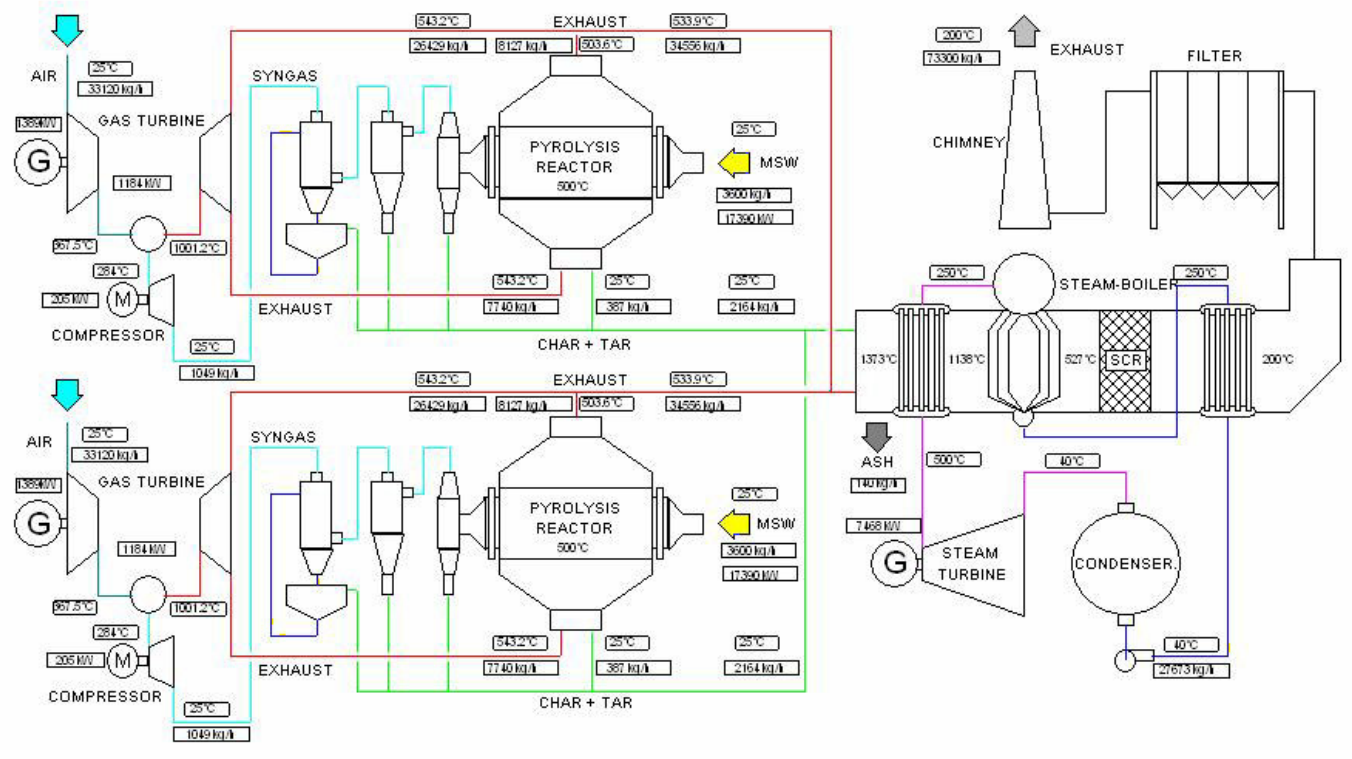


Fig. 2

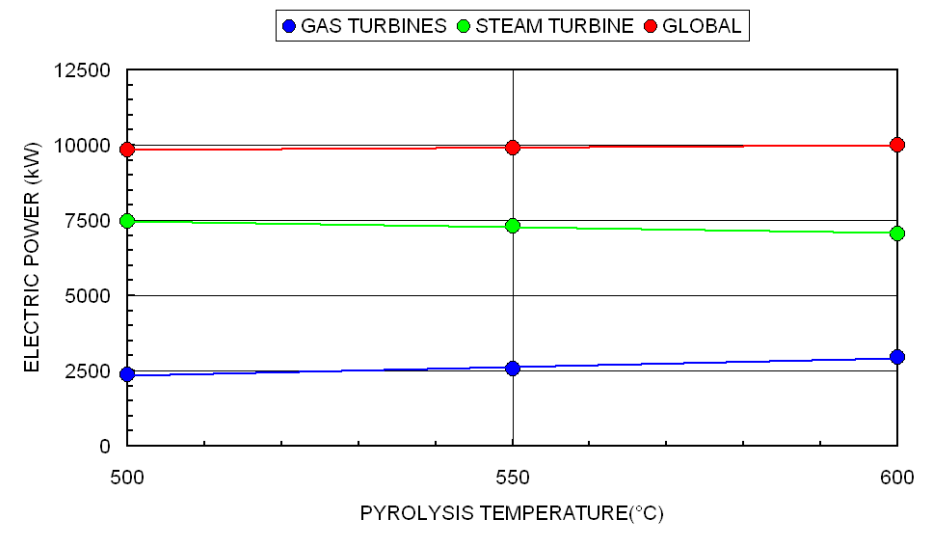




\section{ACCEPTED MANUSCRIPT}

\section{Fig.3}

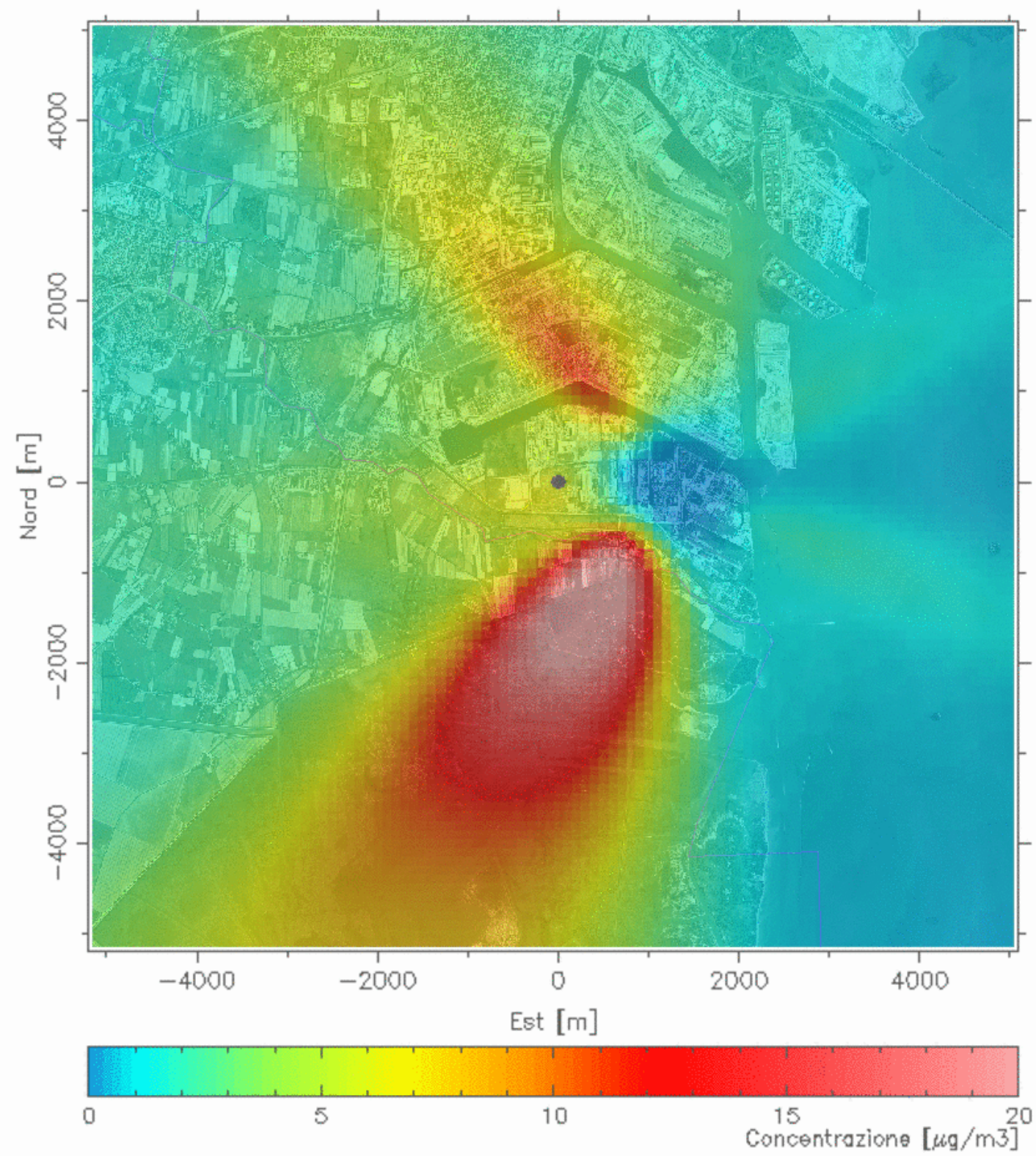




\section{ACCEPTED MANUSCRIPT}

Fig. 4

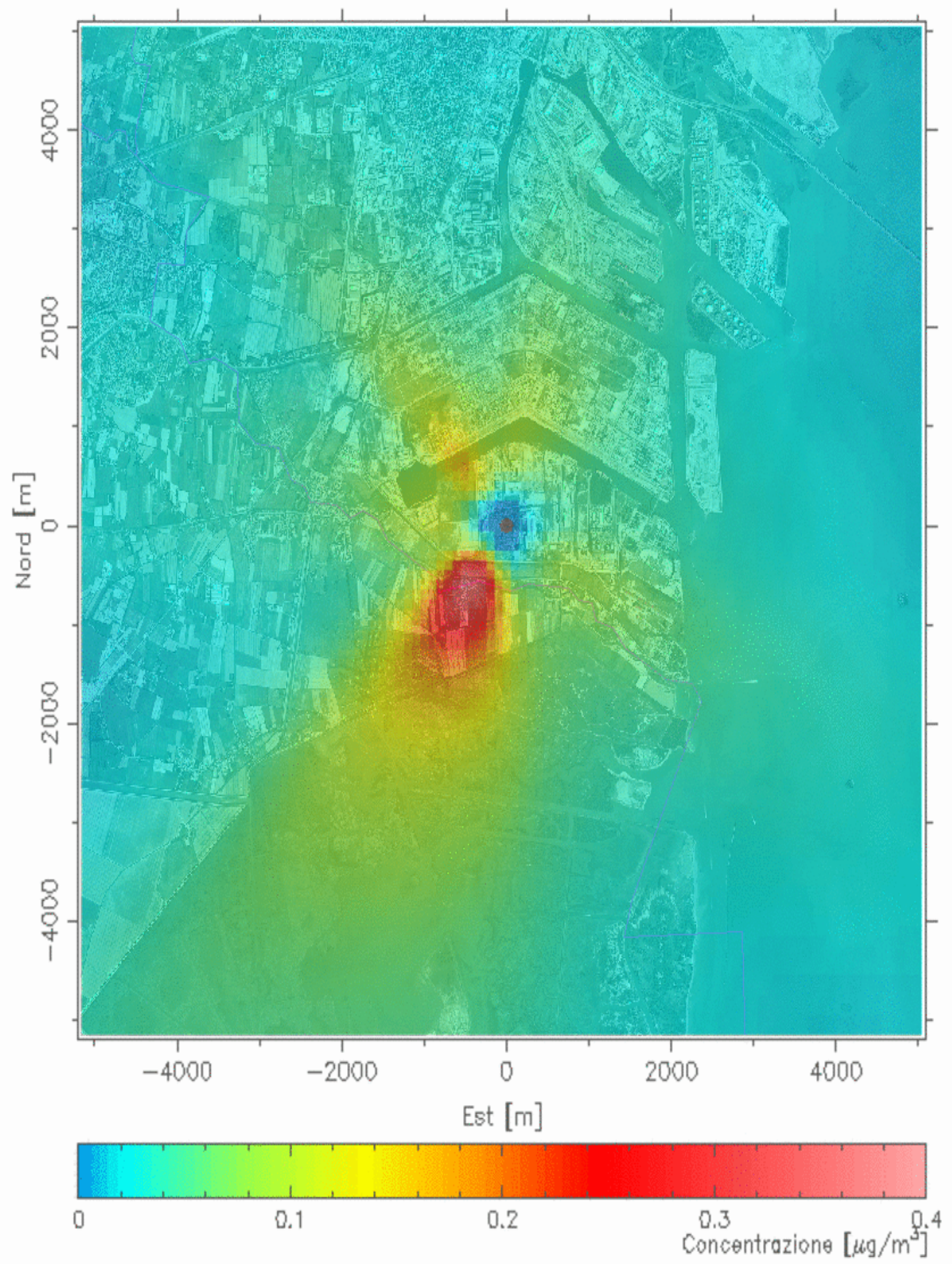




\section{ACCEPTED MANUSCRIPT}

\section{Fig. 5}

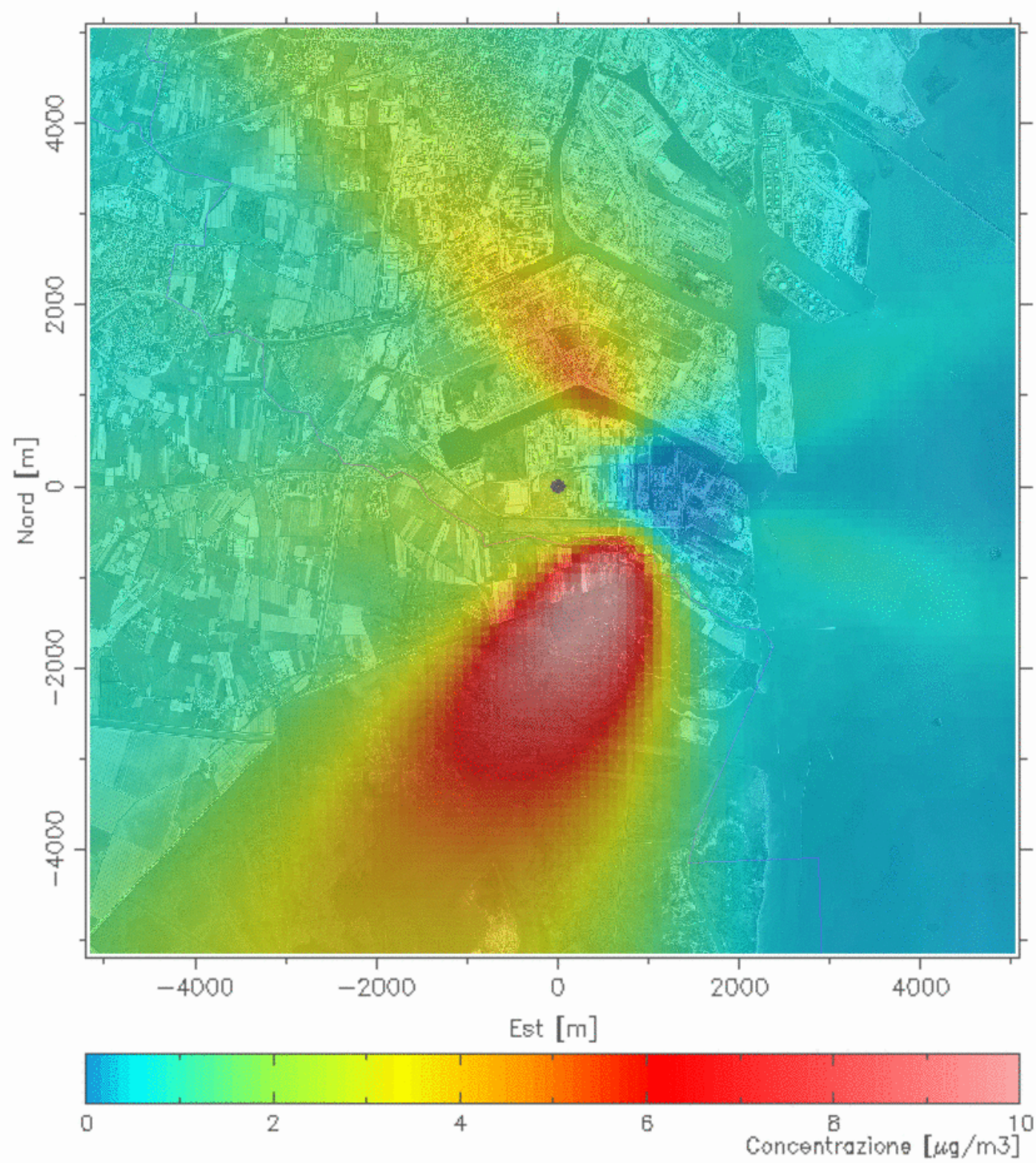




\section{ACCEPTED MANUSCRIPT}

\section{Fig. 6}

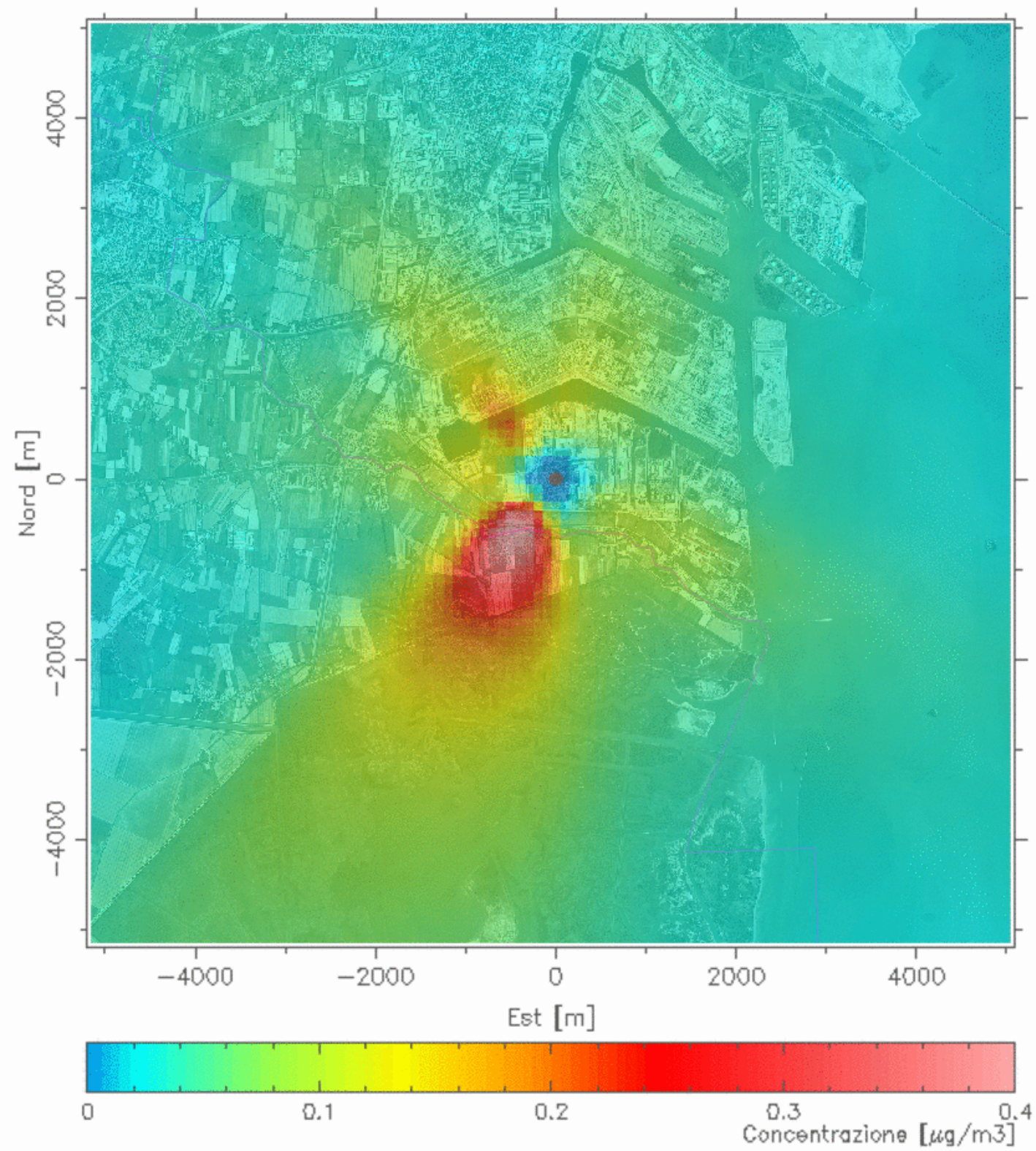




\section{ACCEPTED MANUSCRIPT}

\section{Fig. 7}

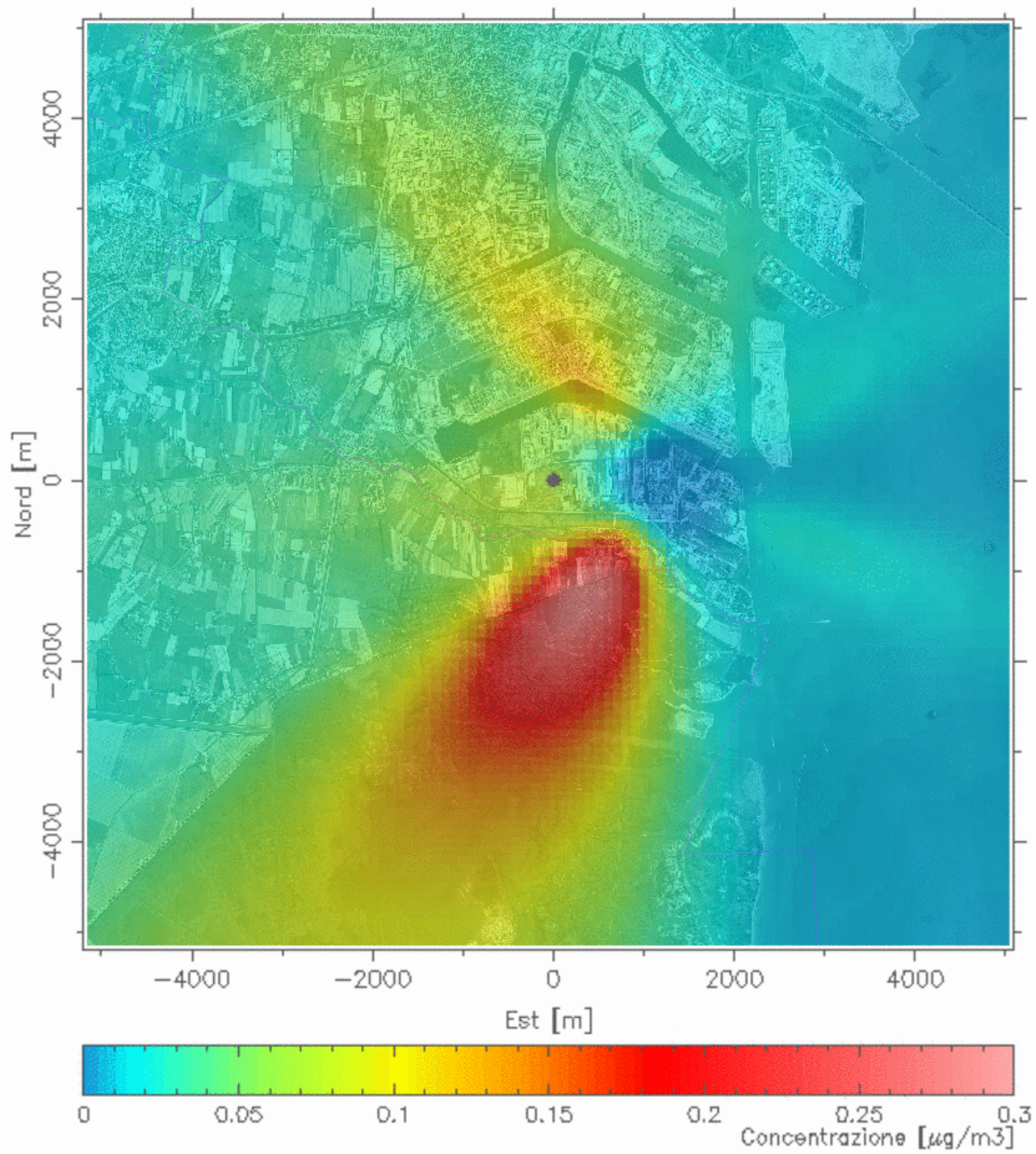




\section{ACCEPTED MANUSCRIPT}

\section{Fig. 8}

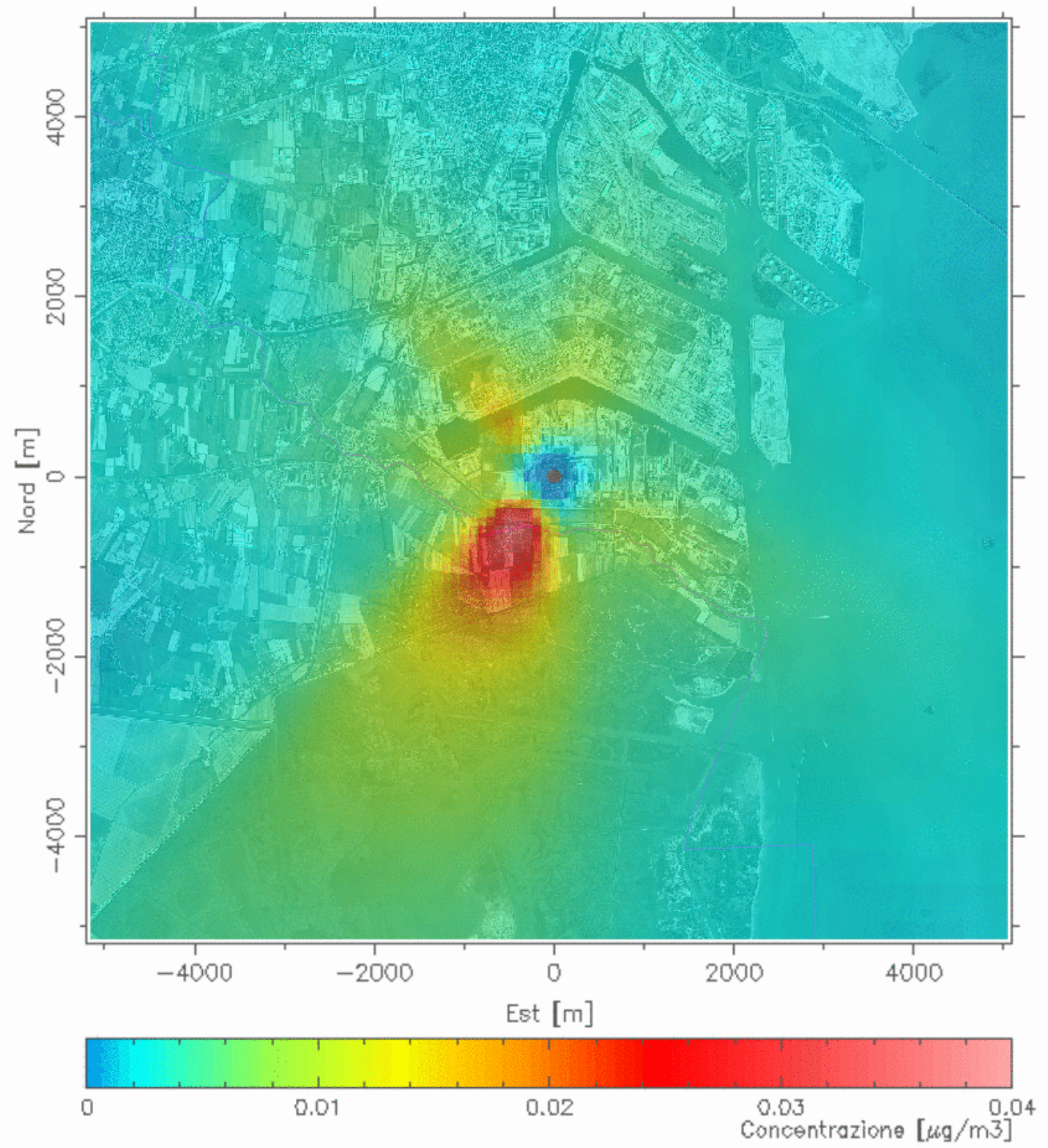




\section{ACCEPTED MANUSCRIPT}

\section{Fig.9}

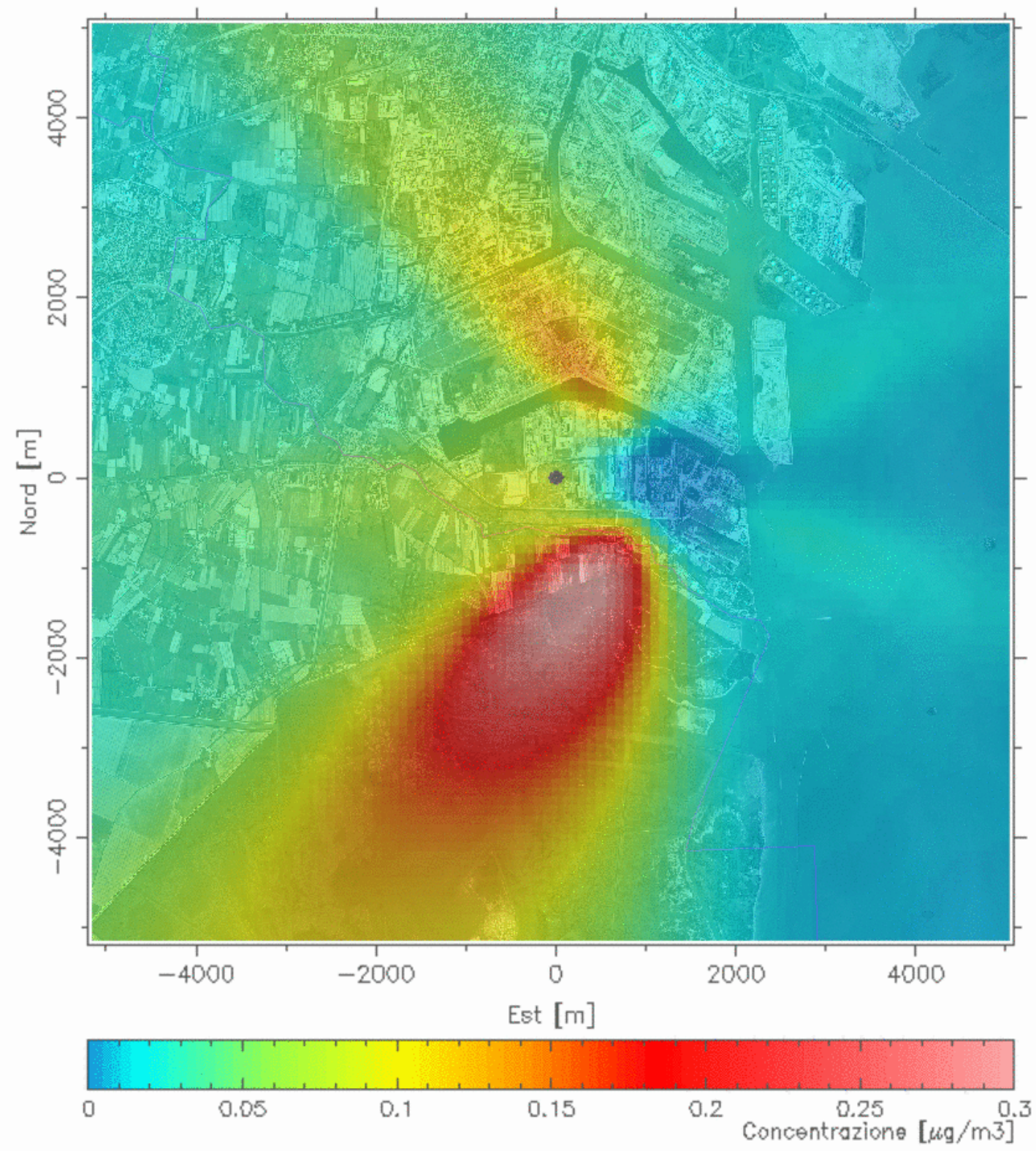




\section{ACCEPTED MANUSCRIPT}

Fig. 10

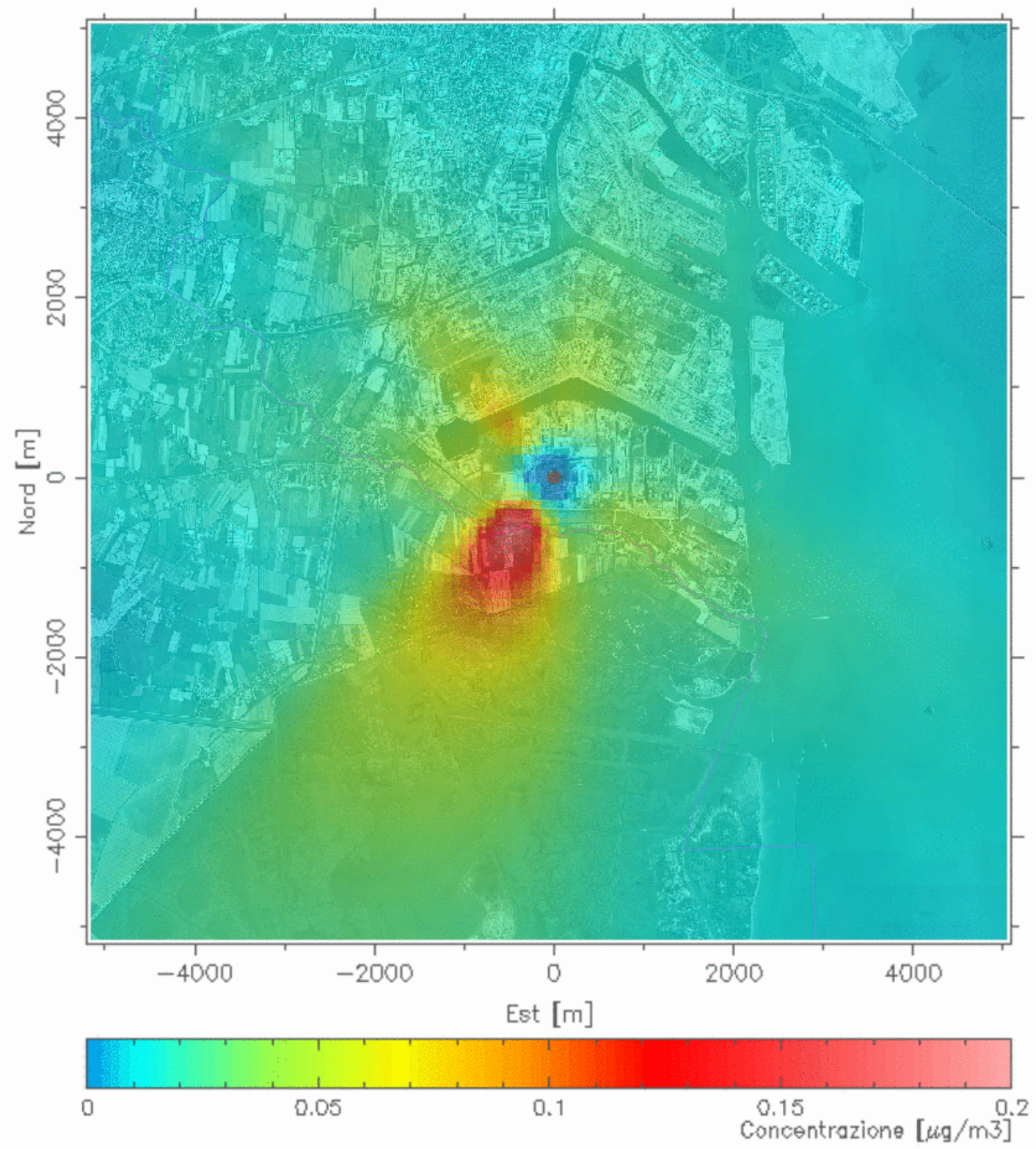

